DOI : https://doi.org/10.31539/jomb.v1i1.603

\title{
PENGARUH INVESTMENT OPPORTUNITY SET DAN PROFITABILITAS TERHADAP KEBIJAKAN DIVIDEND
}

\author{
Winda Astri HIdayat ${ }^{1}$, R Deni Muhammad Danial ${ }^{2}$, Dicky Jhoansyah ${ }^{3}$ \\ Univesitas Muhammadiyah Sukabumi ${ }^{1,2,3}$ \\ Email: windaastri81@gmail.com ${ }^{1}$
}

\begin{abstract}
ABSTRAK
Tujuan dalam penelitian ini yaitu untuk mengetahui pengaruh investment opportunity set (IOS) dan profitabilitas terhadap kebijakan dividend pada perusahaan asuransi yang terdaftar di Bursa Efek Indonesia. Penggunaan metode menggunakan purposive sampling. Teknik analisis yang digunakan adalah teknik analisis linear sederhana, linear berganda, dan untuk pengujian hipotesis adalah uji statistik secara parsial (uji t) dan uji secara simultan (uji f). Hasil penelitian, uji $\mathrm{t}$ menunjukkan bahwa investment opportunity set (IOS (X1) berpengaruh positif tetapi tidak signifikan terhadap kebijakan dividend, Profitabilitas (X2) berpengaruh negatif dan tidak signifikan terhadap kebijkan dividend. Berdasarkan uji $\mathrm{F}$ nilai secara bersama-sama investment opportunity set dan Profitabilitas tidak berpengaruh signifikan terhadap kebijakan dividend (Y). Berdasarkan uji koefisien determinasi sebesar 0,361 dapat diartikan bahwa pengaruh Investment Opportunityy Set (IOS) dan Profitabilitas terhadap kebijakan dividend adalah sebesar $13.03 \%$. Sisanya $86.97 \%$ dipengaruhi oleh faktor lainnya yang tidak djelaskan dalam penelitian ini. Simpulan, Investment Opportunity Set dan Profitabilitas tidak berpengaruh signifikan terhadap kebijakan dividend
\end{abstract}

Kata Kunci: Investment Opporunity Set, Profitabilitas, Kebijakan Dividend

\begin{abstract}
The purpose of this study is to determine the effect of investment opportunity set (IOS) and profitability on dividend policy in insurance companies listed on the Indonesia Stock Exchange. The use of the method uses purposive sampling. The analysis technique used is simple linear analysis, multiple linear analysis, and hypothesis testing is a partial statistical test ( $t$ test) and simultaneous test (f test). The results of the t test show that the investment opportunity set (IOS (XI) influences positive but not significant to dividend policy, Profitability (X2) has a negative and not significant effect on dividend policy.Based on the $F$ value test together the investment opportunity set and profitability do not have a significant effect on dividend policy $(Y)$ Based on the test the coefficient of determination is 0.361 It can be interpreted that the effect of Investment Opportunity Set (IOS) and Profitability on dividend policy is $13.03 \%$, while the remaining $86.97 \%$ is influenced by other factors not explained in this study.
\end{abstract}

Keywords : Investment Opportunity Set, Profitability, Dividend Payout Ratio 


\section{PENDAHULUAN}

Pasar modal memiliki peranan penting untuk memenuhi kebutuhan modal bagi dunia perbisnisan di Indonesia. dalam berinvestasi di pasar modal Indonesia kebanyakan investor lebih memilih perusahaan yang mampu menghasilkan pengembalian modal yang cukup tinggi dan bisa mempertahankan serta mempertinggi tingkat pertumbuhan secara berkelanjutan. Kegiatan investasi yang dilakukan para penanam modal mempunyai tujuan yaitu mencari pendapatan atau tingkat pengembalian investasi baik itu berupa pendapatan (dividen yield) maupun pendapatan dari selisih harga jual saham terhadap belinya.

Kaitannya dengan penghasilan dividend, penanam modal biasanya ingin mendapatkan dividend yang stabil, karena apabila adanya kestabilan dividend akan memberikan peningkatan kepercayaan para penanam modal terhadap perusahaan sehingga memperkecil tingkat ketidak pastian para investor dalam menanamkan modalnya. Untuk mengurangi ketidak percayaan maka manajemen perusahaan membuat suatu kebijaksanan mengenai pembayaran dividend, kebijakan dividend digunakan untuk menentukan besarnya pendapatan yang akan dibagikan pada pemegang saham dan bagian laba yang ditahan oleh perusahaan.

Para investor menginginkan pembayaran dividend yang tinggi sebagai kompensasi dari modal yang mereka tanamkan kepada perusahaan, sedangkan disisi lain para manajemen perusahaan mengiginkan adanya sisa laba ditahan untuk masa yang akan datang dan hendak dipergunsksn untuk melakukan penanaman modal kembali untuk membayar semua kegiatan yang perusahaan jalankan.

Rasio pembagian dividend diduga dipengaruhi oleh Investment Opportunity Set yaitu kombinasi antara aktiva yang dimiliki (assets in place) dan pilihan investasi dimasa yang akan datang dengan NPV positif. Investment Opportunity Set adalah bagian dari nilai perusahaan dan merupakan hasil dari pilihan untuk membuat kebijakan investasi dimasa yang akan datang. Investment Opportunity Set bertujuan untuk menaikan pertumbuhan perusahaan dimana perusahaan lebih cenderung menggunakan dana dari sumber dana internal untuk membiayai kegiatan reinvestasi karena dana tersebut memiliki resiko dan biaya yang cukup kecil. Investment Opportunity Set diduga dapat mempengaruhi dividend yang akan diterima oleh pemegang saham. 
Selain menggunakan investment opportunity set kebijakan dividend juga diduga bisa diukur menggunakan rasio profitabilitas, karena kemampuan rasio profitabilitas mengukur kemampuan perusahaan dalam menghasilkan suatu keuntungan dalam priode tertentu, profitabilitas bisa menjadikan manfaat pada tingkat aktiva dan modal saham tertentu.

Profitabilitas menggambarkan kinerja badan usaha untuk menghasilkan pendapatan (profit) yang menjadikan dasar pemberian dividend perusahaan. Profitabilitas merupakan kinerja perusahaan untuk mendapatkan keuntungan dengan menggunakan seluruh kekayaan yang dimiliki perusahaan. Profitabilitas yang positif menunjukan bahwa total aset yang dipergunakan untuk operasi perusahaan mampu memberikan keuntungan bagi perusahaan. Sebaliknya, jika profitabilitas negatif akan menunjukan total laba perusahaan tidak memberikan keuntungan.

Dividend merupakan pengelompokan aktiva perusahaan kepada para penanam modal. Dividend dapat dikembalikan dalam bentuk uang tunai (kas). Saham perushaaan, ataupun aktiva lainnya. keseluruhan dividend haruslah diumukan oleh dewan direksi sebelum dividen tersebut menjadi kewajiban perusahaa (Suardi, 2014). Apabila perusahaan mengambil keputusan untuk memberi keuntungan yang didapatkan sebeagai dividend berarti akan mengurangi jumlah laba yang akan ditahan yang akhirnya mengurangi sumber dana intern yang akan digunakan untuk mengembangkan perushaan. Sedangkan jika perushaaan tidak membagikan labanya sebagai dividen akan memperbesar sumber dana intern perusahaan dan akan meningkatkan kemampuan perusahaan untuk mengembangkan perusahaan.

\section{KAJIAN TEORI}

\section{Investment Opportunity Set}

Investment Opportunity set menggambarkan tentang luasnya kesempatan atau peluang investasi bagi suatu perusahaan, namun sangat bergantung pada expenditure perusahaan untuk kepentingan dimasa yang akan datang, Investment opportunity Set adalah nilai dari perusahaan untuk melakukan investasi dimasa yang akan datang. Perusahaan yang mempunyai Investment Opportunity Set yang tinggi cenderung akan memberikan dividend yang rendah karena pihak manajemen beranggapan bahwa dana 
tersebut lebih baik tanamkan kembali modalnya kedalam pendapatan yang ditahan demi keberlangsungan perusahaan.

Menurut Myers dalam (Widyawati, 2018) investment opportunity set (IOS) merupakan keputusan investasi dalam bentuk kombinasi antara aktiva yang dimiliki (asset in place) dan pilihan investasi yang akan datang dengan Net Present Velue (NPV) positif yang akan mempengaruhi nilai perusahaan.

Menurut Gever dan Gever dalam (Widyawati, 2018) IOS merupakan nilai perusahaan yang besarnya tergantung pada pengeluaran-pengeluaran yang ditetapkan manajemen dimasa yang akan datang, yang pada saat ini masih merupakan pilihan pilihan investasi yang diharapkan akan menghasilkan return yang lebih besar. Adapun rumus Market To Book Velue Equity adalah sebagai berikut :

$$
M V B V E=\frac{\text { nilai jumlah saham } X \text { saham beredar }}{\text { Totao Equitas }}
$$

\section{Profitabilitas}

Profitabilitas merupakan kemampuan perusahaan mendapakan keuntungan yang berhubungan dengan penjualan, total aktiva maupun modal sendiri. Dividend yaitu sebagian dari penghasilan yang diperoleh oleh perusahaan, dividend akan dibagikan jika perusahaan mendapatkan laba. Keuntungan yang layak diberikan kepada para penanam modal yaitu laba setelah perusahaan memenuhi biaya perushaan, yaitu seperti beban bunga dan pajak. Dividend yang dimaksud adalah keuntungan perusahaan.

Menurut Kasmir (2015) rasio profitabilitas (profitability ratio) merupakan rasio untuk menilai kemampuan perusahaan dalam mencari keuntungan atau laba dalam suatu periode tertentu. Rasio ini juga memberikan ukuran untuk efektivitas manajemen suatu perusahaan yang ditunjukan dari laba yang dihasilkan dari penjualan atau dari pendapatan investasi”. Dikatakan perusahaan rentabilitasnya baik apabila mampu memenuhi target laba yang telah ditetapkan dengan menggunakan aktiva atau modal yang dimilikinya.

Rasio profitabilitas, rasio ini mengukur efektivitas manajemen secara keseluruhan yang ditunjukan oleh besar kecilnya tingkat keuntungan yang diperoleh dalam hubungannya dengan penjualan maupu investasi. Semakin baik rasio 
proditabilitas maka semakin baik menggambarkan kemampuan tingginya perolehan keuntungan perusahaan (Fahmi, 2017)

Profitabilitas dalam penelitian ini diwakili oleh Return On Asset (ROA) yaitu merupakan tingkat pengembalian atas modal perusahaan pada aktiva tetap yang digunakan untuk operasi. Semakin tinggi ROA menunjukan kemampuan perusahaan yang makin baik, karenan tingkat pengembalian investasi (return) semakin besar. Dengan demikian, meningkatkan ROA juga akan meningkatkan pendapatan dividend. profitabilitas merupakan variabel yang penting sebagai dasar pertimbangan para manajer perusahaan dalam rangka menentukan kebijakan dividend. Adapun rumus return

$$
\begin{gathered}
\text { on assets } \quad \text { adalah sebagai } \\
\text { ROA }=\frac{\text { LabaBersih }}{\text { Total Aset }}
\end{gathered}
$$$$
\text { berikut }
$$

\section{Dividend}

Dividend adalah pembagian aktiva suatu perusahaan kepada para pemegang saham perusahaan. Dividend dapat dibayar dalam bentuk uang tunai (kas), saham perusahaan ataupun aktiva lainnya. Semua dividend harus diumumkan oleh dewan direksi sebelum deviden tersebut menjadi kewajiban perusahaan (Suardi, 2014)

Ukuran yang digunakan dalam mengukur kebijakan deviden adalah rasio pembayaran dividend (Dividend Pay out Ratio $=$ DPR). Rasio pembayaran deviden diukur dengan cara membagi besarnya dividend, yaitu dengan jumlah dividend dengan laba bersih perushaan yang secara metematis dapat dinyatakan dengan rumus berikut :

$$
D P R=\frac{\text { dividend }}{\text { laba bersih }}
$$

\section{METODE PENELITIAN}

Metode penelitian yang digunakan peneliti untuk menemukan dan mendapatkan jawaban untuk masalah yang diteliti adalah dengan metode deskriptif dan asosiatif. Deskriptif dilakukan untuk mengatahui nilai variabel mandiri Dalam penelitian ini deskriptif digunakan untuk mengetahui Investment Opportunity set, profitabilitas pada perusahaan-perusahaan asuransi yang terdaftar di BEI. Dalam penelitian ini metode asosiatif digunakan untuk mengetahui pengaruh investment opportunity set terhadap kebijakan dividend, pengaruh profitabilitas terhadap kebijakan dividen. Teknik analisis yang digunakan adalah teknik analisis linear sederhana, analisis linear berganda, dan 
untuk pengujian hipotesis adalah uji statistik secara parsial (uji t) dan uji secara simultan (uji f)

\section{HASIL PENELITIAN}

Untuk melakukan teknik analisis, peneliti menggunakan bantuan perangkat lunak SPSS 24.

Tabel 1

Koefisien Korelasi antara Investment Opportunity Set dan Profitabilitas Terhadap Kebijakan Dividend

\begin{tabular}{lllll}
\hline & & & \multicolumn{2}{l}{ Std. Error of the } \\
Model & $\mathrm{R}$ & R Square & Adjusted R Square & Estimate \\
\hline 1 & $.361^{\mathrm{a}}$ & .130 & .066 & 13.08733 \\
\hline \multicolumn{2}{l}{ a. Predictors: (Constant), PROFITABILITAS, IOS } \\
\hline
\end{tabular}

Berdasarkan perhitungan di atas, dapat diketahui bahwa korelasi variabel investment opportunity set dan profitabilitas adalah sebesar 0,361 (lihat nilai $\mathrm{R}$ pada tabel di atas). Penghitungan koefisien determinasi ini dilakukan untuk mengetahui pengaruh investmentt opportunity set dan profitabilitas terhadap kebijakan dividend pada perushaan asuransi yang terdaftar di BEI. Menurut Sugiyono (2012) dapat dihitung dengan menggunakan rumus koefisien determinasi sebagai berikut:

$$
\mathrm{Kd}=\mathrm{r}^{2} \times 100 \%
$$

Dimana:

$\mathrm{Kd} \quad=$ Koefisien Determinasi

$\mathrm{r} \quad=$ Koefisien korelasi

Perhitungannya adalah sebagai berikut:

$$
\begin{aligned}
\mathrm{Kd} & =\mathrm{r}^{2} \times 100 \% \\
& =(0,361)^{2} \times 100 \% \\
& =0,130 \times 100 \% \\
& =13,03 \%
\end{aligned}
$$

Berdasarkan perhitungan koefisien determinasi yang telah peneliti lakukan, diketahui bahwa nilai $\mathrm{Kd}=13,03 \%$ sedangkan sisanya $86,97 \% \quad(100 \%$ $13,03 \%=86,97 \%$ ) dari faktor yang tidak diteliti. Maka dapat disimpulkan bahwa investment opportunity set dan profitabilitas terhadap kebijakan dividend sangat rendah 
dan $\mathrm{Kd}$ mendekati 0 maka pengaruh investment opportunity set dan Profitabilitas terhdap kebijakan dividend lemah.

Tabel 2

Hasil Perhitungan Regresi Linear Berganda

\begin{tabular}{|c|c|c|c|c|c|c|}
\hline \multicolumn{7}{|c|}{ Coefficients $^{\mathrm{a}}$} \\
\hline \multirow[b]{2}{*}{ Model } & & \multicolumn{2}{|c|}{ Unstandardized Coefficients } & \multirow{2}{*}{$\begin{array}{c}\begin{array}{c}\text { Standardized } \\
\text { Coefficients }\end{array} \\
\text { Beta }\end{array}$} & \multirow[b]{2}{*}{$\mathrm{T}$} & \multirow[b]{2}{*}{ Sig. } \\
\hline & & $\mathrm{B}$ & Std. Error & & & \\
\hline 1 & (Constant) & 31.604 & 2.861 & & 11.046 & .000 \\
\hline & IOS & .005 & .019 & .143 & .256 & .800 \\
\hline & PROFITABILITAS & -.345 & .391 & -.493 & -.881 & .386 \\
\hline
\end{tabular}

Dari hasil output SPSS 24 di atas, dapat diketahui persamaan regresi ganda yaitu:
$\mathrm{a}=31,604$
$\mathrm{b}_{1} \quad=0,005$
$\mathrm{b}_{2} \quad=-0,345$

Selanjutnya didapat persamaan regresi linier berganda untuk dua predikator (investment opportunity set dan profitabilitas ) adalah:

$\mathrm{Y}^{*}=31,604+0,005 \mathrm{X}_{1}-0,345 \mathrm{X}_{2}$. Berdasarkan persamaan di atas, diketahui terdapat pengaruh positif antara investment opporunity set (variabel X1) dan negatif profitabilitas (variabel X2) terhadap kebijakan dividend (variabel Y).

1. Angka konstanta sebesar 31,604 menyatakan bahwa tidak ada investment opportunity set dan profitabilitas maka kebijakan dividend akan sebesar 32 ( dibulatkan dari 31,604).

2. Koefesien regresi 0,005 (X1) menyatakan bahwa setiap penambahan 1 kali investment opportunity set maka akan meningkatkan kebijakan dividend sebesar 0.005 .

3. Koefesien regresi profitabilitas $-0,345$ (X2) menyatakan bahwa setiap peneambahan 1 kali profitabilitas maka akan mengalami penurunan kebijakan dividend sebesar 0,345 . 
Tabel 3

Hasil Uji T dan Uji F

\begin{tabular}{|c|c|c|c|c|c|c|}
\hline \multicolumn{7}{|c|}{ Coefficients $^{\mathrm{a}}$} \\
\hline & \multirow[b]{2}{*}{ Model } & \multicolumn{2}{|c|}{ Unstandardized Coefficients } & \multirow{2}{*}{$\begin{array}{l}\text { Standardized } \\
\text { Coefficients } \\
\text { Beta } \\
\end{array}$} & \multirow[b]{2}{*}{$\mathrm{T}$} & \multirow[b]{2}{*}{ Sig. } \\
\hline & & $\mathrm{B}$ & Std. Error & & & \\
\hline \multirow[t]{3}{*}{1} & (Constant) & 31.604 & 2.861 & & 11.046 & .000 \\
\hline & IOS & .005 & .019 & .143 & .256 & .800 \\
\hline & $\begin{array}{l}\text { PROFITABILITA } \\
\text { S }\end{array}$ & -.345 & .391 & -.493 & -.881 & .386 \\
\hline
\end{tabular}

a. Dependent Variable: DPR

Dari hasil pengujian dapat dilihat bahwa variabel investment opportunity set memiliki $t$ hitung sebesar 0.256 dengan $t$ tabel sebesar 1,701 sementara tigkat signifikan lebih besar daripada tingkat signifikansi yang telah ditetapkan yaitu $0.800>$ 0.005. Untuk taraf kesalahan sebesar $5 \% \mathrm{t}$ tabel $\mathrm{dk}=\mathrm{n}-2=28$ maka di peroleh $\mathrm{t}$ tabel sebesar 2,048. Maka hasil pengujian hipotesis t hitung $0.256<2.048$. Hal ini menunjukan bahwa investment opportunity set memiliki pengaruh positif terhadap kebijakan dividend tetapi tidak signifikan pada perusahaan asuransi yang terdaftar di Bursa Efek Indonesia

Berdasarkan hasil pengujian dapat dilihat bahwa variabel profitabilitas memiliki koefesien sebesar -0.354 dan thitung sebesar -0.881. sementara rigkat signifikan lebih besar daripada tingkat signifikasi yang telah di tetapkan yaitu $0.386>0.005$. Untuk taraf kesalahan sebesar 5\% t tabel $\mathrm{dk}=\mathrm{n}-2=28$ maka di peroleh $\mathrm{t}$ tabel sebesar 2,048. Maka hasil pengujian hipotesis t hitung $-0.354<2.048$. Hal ini menunjukan bahwa profitabilitas memilikii pengaruh negatif terhadap kebijakan dividend dan tidak signifikan pada perusahaan asuransi yang terdaftar di Bursa Efek Indonesia.

Tabel 4

Hasil Uji F

\begin{tabular}{llrrrrr}
\hline \multicolumn{7}{c}{ Hasil Uji F $^{\text {ANOVA }}$} \\
\hline \multicolumn{7}{c}{ ANOVA $^{\mathbf{a}}$} \\
\hline Model & & Sum of Squares & Df & Mean Square & F & Sig. \\
\hline \multirow{2}{*}{1} & Regression & 690.852 & 2 & 345.426 & 2.017 & $.153^{\text {b }}$ \\
\cline { 2 - 7 } & Residual & 4624.515 & 27 & 171.278 & & \\
\cline { 2 - 7 } & Total & 5315.367 & 29 & & & \\
\hline
\end{tabular}

a. Dependent Variable: DPR

b. Predictors: (Constant), PROFITABILITAS, IOS 
Berdasarkan tabel diatas dapat dilihat pengaruh simultan variabel bebas terhadap variabel independen investment opportunity set dan profitabilitas terhadap variabel dependen kebijakan dividend. Berdasarkan hasil uji simultan diperoleh F hitung sebesar 2.017 dengan tigkan signifikansi sebesar 0,153. Berdasarkan nilai signifikansi yang lebih besar dari 0.05 maka, dapat dikatakan bahwa investment opportunity set dan profitabilitas secara bersama-sama tidak berpengaruh terhadap kebijakan dividend. Berdasarkan $\mathrm{F}$ tabel dengan dk pembilang $=2$ dan dk penyebut $=30-2-1=27$ dengan taraf kesalahan yang ditetapkan sebesar 5\% maka diperoleh nilai $\mathrm{F}$ tabel $=3,35$. Maka hasil pengujian hipotesis adalah $\mathrm{F}$ hitung $<\mathrm{F}$ tabel 2,017 <3,35 maka tidak signifikan.

\section{PEMBAHASAN}

\section{Pembahasan Secara Parsial}

Hasil analisis statistik untuk variabel investment opportunity set diketahui bahwa koefesien regresi bernilai positif. Hasil uji t untuk investment opportunity set diperoleh nilai sebesar 0.256 dan $\mathrm{t}$ hitung sebesar 1,701. dengan tingkat signifikansi lebih besar di bandingkan dengan taraf signifikansi yang di tetapkan yaitu $0.800>0.05$ hal ini menunjukan bahwa investment opportunity set memiliki pengaruh terhadap kebijakan dividend tetapi tidak signifikan pada perusahaan asuransi yang terdaftar di Bursa Efek Indonesia. Dengan kata lain $\mathrm{Ha}_{1}$ dalam penelitian ini ditolak.

Menurut Dithi (2012) investment opportunity set berpengaruh negatif namun tidak signifikan terhadap kebijakan dividend. Apabila kondisi suatu perusahaan sangat baik maka pihak manajemen akan cenderung lebih memiliih investasi baru daripada membayar dividend, dana yang seharusnya dibayarkan kepada para pemegang saham akan digunakan untuk pembelian investasi. Tetapi pada penelitian ini menunjukan bahwa investment opportunity set berpengaruh positif tetapi tidak signifikan, hasil analisis ini sependapat dengan Haryeti dan Ekayati (2012), Ayu (2014) yang menunjukan bahwa investment opportunity set berpengaruh positif tetapi tidak signifikan terhadap kebijakan dividend.

Hasil analisis statistik untuk variable profitabilitas diketahui hasil uji t untuk profitabilitas diperoleh nilai sebesar -0.354 dan $\mathrm{t}$ hitung sebesar1,701 dengan tingkat signifikansi lebih besar di bandingkan taraf signifikasi yang telah di tetapkan yaitu $0.386>0.05$ hal ini menunjukan bahwa profitabilitas memiliki pengaruh negatif 
terhadap kebijakan dividend dan tidak signifikan pada perusahaan asuransi yang terdaftar di Bursa Efek Indonesia. Dengan kata lain $\mathrm{Ha}_{2}$ dalam penelitian ini ditolak.

Secara persial profitabilitas berpengaruh negatif terhadap kebijakan devidend hasil penelitian ini sesuai dengan penelitian yang dilakukan oleh Idawati (2014) menunjukan bahwa Return On Aset berpengaruh negatif dan tidak signifikan terhadap kebijakan devidend. Profitabilitas adalah kemampuan perusahaan dalam menghasilkan laba sedangkan devidend merupakan sebagian laba dari perusahaan yang disalurkan kepada investor. Dengan hasil ini dapat disimpulkan bahwa pada penelitian ini proftabilitas tidak mempengaruhi kemampuan perusahaan membagikan devidend, perusahaan mungkin tidak membagikan devidend yang tinnggi dari hasil profit.

\section{Pembahasan Secara Simultan}

Berdasarkan hasil uji simultan (Uji $F$ ) variabel independen investment opportunity set dan profitabilitas terhadap variabel dependen kebijakan dividend. Berdasarkan hasil uji simultan diperoleh $\mathrm{F}$ hitung sebesar 2.017 dengan tingkat signifikansi sebesar 0,153. Berdasarkan nilai signifikansi yang lebih besar dari 0.05 maka, dapat dikatakan bahwa investment opportunity set dan profitabilitas secara bersama-sama tidak berpengaruh terhadap kebijakan dividend.

Berdasarkan Uji Koefesien Determinasi dapat dilihat nilai Adjusted $R^{2}$ sebesar 0,361 dapat diartikan bahwa pengaruh Investment Opportunityy Set (IOS) dan Profitabilitas terhadap kebijakan dividend adalah sebesar $13.03 \%$. Sisanya $86.97 \%$ dipengaruhi oleh faktor lainnya yang tidak djelaskan dalam penelitian ini.

\section{SIMPULAN}

1. Secara parsial, Investment Opportunity Set berpengaruh tetapi tidak signifikan terhadap kebijakan dividend pada perusahaan asuransi yang terdaftar di Bursa Efek Indonesia

2. Secara parsial, Profitabilitas berpengaruh negatif dan tidak signifikan terhadap kebijakan dividend pada perusahaan asuransi yang terdaftar di Bursa Efek Indonesia 
3. Berdasarkan uji F, variabel Investment Opportunity Set dan Profitabilitas tidak berpengaruh signifikan secara bersama-sama (simultan) terhadap kebijakan dividend pada perusahaan asuransi yang terdaftar di Bursa Efek Indonesia

\section{DAFTAR PUSTAKA}

Ayu. (2014). Faktor-Faktor yang Berpengaruh Terhadap Kebijakan Deviden. Jurnal Universitas Diponegoro. 3 (3): 67-77

Fahmi, I. (2017). Analisis Laporan Keuangan . Bandung: Alfabeta.

Haryeti dan Ekayati Ririn Araji. (2012). Pengaruh Profitabilitas, Investment Opportunity Set dan Pertumbuhan Perusahaan Terhadap Kebijakan Deviden Pada Perusahaan LQ 45 Yang terdaftar di BEI. Jurnal Ekonomi.

Idawati. (2014). Pengaruh Profitabilitas, Likuiditas, Laverage, ukuran perusahaan terhadap kebijakan devidend Perusahaan Manufaktur. E-jurnal Akuntansi Universitas Undayana. 36 (1): 89-99

Kasmir. (2015). Analisis Laporan Keuangan . Jakarta: PT Raja Grafindo Persada.

Suardi. (2014). Pengaruh Profitabilitas dan Investment Opportunity Set Terhadap Deviden Tunai Perusahaan Go Public Sektor Perbankan Bursa Efek Indonesia. Jurnal Ilmiah Saintikom.

Sugiyono. (2012). Metode Penelitian Kuantitatif, Kualitatif. Bandung : Alfabeta .

Putri, Dithi. A. (2013). Pengaruh Investment Opportunity Set, Kebijakan Utang Dan Ukuran Perusahaan Terhadap Kebijakan Dividen. Studi Empiris Pada Emiten Pembentuk Indeks LQ-45 di Bursa Efek Indonesia. Jurna Akuntansi, 1 (1): 4555

Widyawati, R. D. (2018). Pengaruh Kesempatan Investasi, Pofitabilitas Dan Likuiditas Terhadap Kebijakan Deiden Pada Perusahaan Manufaktur yang Terdaftar di BEI . Ekonomi dan Bisnis . 